\title{
Gemi geri alım programının ve büyük gemi sahibi balıkçıların programa katılmamalarının değerlendirilmesi
}

\section{Evaluation of vessels buyback program and non-participation of large ship-owners}

\author{
Esra Erikci BİLGín ${ }^{1}$, Serpil YILMAZ ${ }^{2}$
}

${ }^{1}$ Piri Reis Üniversitesi, Denizcilik Fakültesi, Tuzla, İstanbul

${ }^{2}$ Akdeniz Üniversitesi, Su Ürünleri Fakültesi, Temel Bilimler Bölümü, Antalya.

Sorumlu yazar (Corresponding author): S. Y1lmaz, e-posta (e-mail): serpilyilmaz@akdeniz.edu.tr

Yazar(lar) e-posta (Author e-mail): esraerikcibilgin@yahoo.com

\section{MAKALE BİLGİSİ}

Alınıs tarihi 03 Eylül 2019

Düzeltilme tarihi 16 Ekim 2019

Kabul tarihi 22 Ekim 2019

\section{Anahtar Kelimeler:}

Balıkçılık

Balıkçılık yönetimi

Gemi geri alım programı

Türkiye

\begin{abstract}
ÖZ
Ülkemizde uygulanan hatalı balıkçılık teknikleri ve avlanma baskısı nedeniyle ekosistem ve balık stokları zarar görmektedir. Bu sorunu çözmenin en önemli araçlarından birisi ise devlet desteği ile uygulanan geri alım programlarıdır. Türkiye'de de 2013-2015 yıllarında uygulanan geri alım programı ile filoda etkin bir azalma vasitasıyla, av baskısının azaltılması ve sürdürülebilir balıkçılığın sağlanması amaçlanmıştır. Programa katılım oranı 30 metre ve üstündeki gemilerde oldukça düşük olarak gerçekleşmiştir. Bu nedenle bu çalışmada 30 metre ve üzerindeki tekne sahiplerinin programdan yararlanmama nedenlerinin irdelenmesi amaçlanmıștır. Calıșmada, basit tesadüfi örnekleme yöntemi kullanılarak ve tesadüfi olarak seçilen 73 balıkçı ile yapılan yüz yüze görüşmelerden elde edilen veriler temel olarak kullanılmıştır. Çalışma sonucunda, programa katılmama kararında, en büyük etken olarak ekonomik nedenler ileri sürülmüştür. Gemi geri alım programında hedef kitle için belirlenen bedelin, balıkçılara yetersiz gelmesi, programa katılmamanın en önemli nedenlerinden birisi olarak belirlenmiștir. İlave olarak söz konusu balıkçıların destekten daha fazlasını kazanıyor olması, tekne yenileme ve ruhsat satışı yapabilme olanaklarının bulunması en çok dikkate alınan diğer faktörlerdir. Balıkçılığın baba mesleği olması da (\%86) kararda etkili olan bir faktör olarak belirtilmiştir.
\end{abstract}

\section{ARTICLE INFO}

Received 03 September 2019

Received in revised form 16 October 2019

Accepted 22 October 2019

\section{Keywords:}

Fishing

Fisheries management

Vessels buyback program

Turkey

\begin{abstract}
Ecosystem and fish stocks are damaged due to faulty fishing techniques and hunting pressure applied in our country. One of the most important tools to solve this problem is the statefunded buyback programs. Turkey as in the fleet with the retrieval program implemented in 2013-2015 years by means of an active reduction, the reduction of fishing pressure and is intended to achieve sustainable fishing. Participation in the program was very low for ships above 30 meters. Therefore, in this study, it is aimed to examine the reasons why the owners of boats over 30 meters and over do not benefit from the program. In this study, data obtained from face-to-face interviews with 73 randomly selected fishermen were used as the basis of simple random sampling method. As a result of this study, economic reasons have been put forward as the biggest factor in the decision not to participate in the program. The fact that the price determined for the target audience in the ship buyback program is less for the fishermen has been determined as one of the most important reasons for not participating in the program. In addition, the fact that these fishermen gain more than support, and the possibility of boat renewal and license sale are other factors that are most taken into consideration. The fact that fishery is the father's profession $(86 \%)$ has been stated as an effective factor in the decision.
\end{abstract}

\section{Giriş}

Son yıllarda tüm dünyada uygulanan hatalı balıkçılık teknikleri ve aşırı avlanma nedeniyle özellikle ekosistem ve balık stokları zarar görmektedir. $\mathrm{Bu}$ durum balıkçılıkta sürdürülebilirliğin sağlanması açısından önemli sakıncalar yaratmaktadır. Nitekim dünya genelinde balık stoklarında aşırı avcılık yapılan stoklar \%31.4, tam kapasite ile avcılı̆g yapılan stoklar \%58.1, normal avcılığ yapılan stoklar ise \%10.5 olarak tespit edilmiştir (FAO 2016). Ayrıca Akdeniz Genel Balıkçılık Konseyi, Akdeniz'deki stokların \%80'inin emniyetli biyolojik sınırların dışında olduğunu belirtmiş ve uygulanacak balıkçılık 
yönetiminde Deniz Koruma Konseyi (MCS) sistemlerinin kullanılması gerektiğini ifade etmiştir. 2015 yılı itibariyle sürdürülemez düzeydeki stoklar arasında değerlendirilen 16 istatistiki bölge arasında, ülkemizin de içerisinde yer aldığı Akdeniz ve Karadeniz Bölgesi \%62.2 oranı ile en yüksek değere sahip olan bölge durumundadır (FAO 2018). Bu değerler, bu konuda acil önlemler alınması gerektiğini ifade etmektedir.

$\mathrm{Bu}$ soruna yol açan faktörlerden en önemlisi kuşkusuz balıkçı gemisi filosunun büyüklüğüdür. $\mathrm{Bu}$ açıdan değerlendirildiğinde Türkiye'nin önemli bir balıkçı gemisi filosuna sahip olduğu görülmektedir. 2017 y1lı verilerine göre, Türk sularında (deniz + iç su) 15406 ruhsatlı balıkçı teknesi bulunmaktadır (SUBİS 2018). Bu değer, AB ülkelerindeki tekne sayıları ile karşılaştırıldığında Türkiye en başta gelmektedir. AB ülkeleri içinde en yüksek tekne sayıs1 14977 gemi ile Yunanistan'dadir (EUROSTAT 2018).

$\mathrm{Bu}$ çerçevede balık stokları üzerindeki avlanma baskısı sorununu çözmenin en önemli araçlarından birisi olarak, balıkçı gemisi sayısının azaltılmasına yönelik politika uygulamaları karşımıza çıkmaktadır. Söz konusu program ilk kez 1970 yılında Kanada'da somon balıkçılığında uygulanmış olup, toplam 4 programda aşamalı olarak ilerlemiştir (Kurt ve Muse 1984). Daha sonra başta Avrupa Birliği (AB) ülkeleri olmak üzere balıkçılıkta gelişmiş ülkeler ve Türkiye'de, balıkçı gemisi geri alım programları uygulamaları gerçekleştirilmiştir. Türkiye'de 2012 yılı itibariyle Gıda Tarım ve Hayvancılık Bakanlığı tarafından başlatılan, 2013-2015 yıllarında üç defa olmak üzere ve her bir y1l için ayrı olarak çıkartılan tebliğler ile uygulanan gemi geri alım programının amacı da filoda etkin bir azalma sağlamak ve balık üzerindeki av baskısını azaltarak sürdürülebilir balıkçılığı oluşturmak olmuştur. 12 metre ve üzeri gemilerin geri alımı ile başlayan program, daha sonra 10 metre ve üzeri olarak revize edilmiş, ayrıca, büyük teknelerin başvurmalarını sağlamak amacıyla destek miktarı değiştirilmiştir. Ancak bazı olumsuzluklar sebebiyle, Türkiye'de uygulanan gemi geri alım programında önemli bir başarı sağlanamamıştır. Özellikle programa katılım oranı 30 metre ve üstündeki gemilerde oldukça düşük olarak gerçekleşmiştir. Dolayısıyla büyük tekne sahiplerinin programa katılmama nedenlerinin araştırılması önem taşımaktadır.

Türkiye'de balıkçıları konu alan sınırlı sayıda çalışmaya rastlanmıştır ve çalışmalar belirli bölgelerde balıkçıların sosyoekonomik özelliklerini ortaya koymuştur (Uzmanoğlu ve Soylu 2006; Yücel 2006; Dartay ve ark. 2009; Yiğit ve ark. 2009; Doğan ve Gönülal 2011; Aksoy ve Koç 2012; Yaylığlu 2013). Ayrıca farklı denizlerde avcı balıkçıların faaliyetlerinin ekonomik analizine yönelik çalışmalar da yapılmıştır. Bu kapsamda Foça'da (Ünal ve Hoşsucu 1996; Ünal 2001; Ünal 2002; Ünal 2003; Ünal 2004), Karadeniz'de (Çeliker ve ark. 2006), Ege Denizinde (Çeliker ve ark. 2008) ve Akdeniz'de (Taşdan ve ark. 2010), Mersin Taşucu'nda ( $\operatorname{Rad}$ ve Delioğlan 2006), Samsun'da (Ceyhan ve Gene 2014) Marmara'da (Güngör ve ark. 2007, Güngör ve ark. 2019) yapılan çalışmalar belirtilebilir. Gemi alım programı konusundaki yayınlar ise Y1lmaz ve ark. (2017), Göktay ve ark. (2018) ile Ekmekçi ve Ünal (2019) tarafindan gerçekleştirilmiştir. Söz konusu çalışmalarda $\mathrm{AB}$ sürecinde gemi geri alım programının gelişimi, ilk balıkçı gemisi geri-alım programının analizi ve ikinci kuşak balıkçı gemisi geri-alım programının analizi yapılmıştır.

Bu çalışmada ise denizlerimizdeki stoklar üzerinde oldukça baskın olan 30 metre ve üzeri tekne sahiplerinin programdan yararlanmama nedenlerinin irdelenmesi, bu çerçevede gemi geri alım programının başarısının araştırılması amaçlanmıştır. İlave olarak programın uygulanmasının incelenmesi ve karşılaşılan sorunların ortaya konularak, çözüm önerilerinin getirilmesi hedeflenmiştir.

\section{Materyal ve Yöntem}

Çalışmanın hedef kitlesini, 30 metre ve üzeri balıkçı teknelerinin, balık stokları üzerinde daha etkin olduğu hipotezi esas alınarak, $30 \mathrm{~m}$ ve üzeri tekne sahibi balıkçılar oluşturmuştur. Çalışmada kullanılan birincil veriler, programdan yararlanmayan balıkçı tekne sahipleriyle, hazırlanan anket formları kullanılarak yüz yüze yapılan görüşmelerle elde edilmiştir. Söz konusu anket çalışması Karadeniz, Marmara ve Ege Bölgesinde av yasağı döneminde (Nisan-Eylül 2018) gerçekleştirilmiştir. Ayrıca, Balıkçılık ve Su Ürünleri Genel Müdürlüğü, Su Ürünleri Bilgi Sistemi (SUBİS) kayıtları, Tarım Orman Bakanlığı sirküler ve istatistikleri, Türkiye İstatistik Kurumu (TÜIK) verileri, Devlet Planlama Teşkilatı Kalkınma Planları (DPT), AB Komisyonunun AB İlerleme Raporları ve paydaşlardan toplanan veriler ile geri-alım programı ile ilgili çalışmalar araştırmada ikincil veri olarak kullanılmıştır.

Söz konusu balıkçı gemilerinin özellikleri, SUBİS bilgisayar kayıtlarından elde edilerek örneklemeye esas çerçeve oluşturulmuştur. Toplam 251 teknenin en küçügüunün $30 \mathrm{~m}$, en büyüğ̈nün $62 \mathrm{~m}$, ortalama boyunun $38 \mathrm{~m}$, standart sapmasının $6.25 \mathrm{~m}$ ve varyansının 39 olduğu tespit edilmiştir. Popülasyon büyük olmadığından ve göreceli olarak homojen olarak nitelendirilebileceği için basit tesadüfi örnekleme ile örnek hacminin hesaplanmasının uygun ve yeterli olacağ düşünülmüştür (Yamane 1967). Araştırmada tekne boyları değişken olarak alınarak, aşağıda verilen basit tesadüfi örnekleme eşitliği kullanılarak örnek sayısı belirlenmiştir.

$$
n=\frac{N(Z S)^{2}}{N d^{2}+(Z S)^{2}}
$$

Burada;

n: Örnek büyüklüğü

$\mathrm{N}$ : Popülasyondaki birim sayıs1

$\mathrm{S}^{2}$ : Varyans

S: Standart sapma

d: Kabul edilebilen sapma miktarı $(1.3 \mathrm{~m})$

Z: Güven derecesine (\%95) göre standart normal dağılım tablosundaki z değeridir (1.96).

Örnek sayısı 73 olarak hesaplanmış ve balıkçılar tesadüfi olarak seçilerek anket yapılmıştır. Bu çerçevede deneklerden, sosyal ve demografik veriler (tekne sahibinin yaşı, cinsiyeti, eğitim düzeyi, medeni hali, sosyal güvencesi vb.), ekonomik veriler (geliri, teknenin nitelikleri, çalışan sayısı, ücret ödeme şekli, yıl içinde çalışılan gün sayısı vb.), programa ilişkin olarak geri alım programına yönelik görüşler elde edilmeye çalışılmıştır. Özellikle balıkçıların çeşitli konulardaki düşüncelerinin belirlenmesinde likert ölçeğinden yararlanılmıştır. Verilerin değerlendirilmesinde SPSS programı kullanılmıştır. Sonuçlar, tanımlayıcı istatistiklerle sunulmuştur. İncelenen değişkenlerin balıkçıların sosyo-ekonomik özellikleri ve çeşitli gruplar itibariyle ile farklılık gösterip göstermediği test edilmiştir. Bu çerçevede kategorik değişkenlerin istatistiksel analizinde ki kare testlerinden yararlanılmıştır. Ki kare testlerinin doğru sonuçlar verebilmesi için her bir hücreye düşen frekansın 3 ve daha fazlası olması gerekmektedir. Bu durumun sağlanamaması hallerinde gruplar arasında birleştirmeler 
yapılmıştır. Diğer taraftan sürekli değişkenlere ilişkin grup ortalamaları arasındaki farklılığın analizinde tek yönlü varyans analizi (ANOVA) yapılmıştır.

\section{Bulgular}

\subsection{Gemi geri alım programının incelenmesi}

Beş yıllık kalkınma planlarında görülebileceği gibi, 19631967 yılları arasında raporlanan su ürünleri üretimi 155000 tonlardayken, 1988 yılında yine 6 . beş yıllık kalkınma planında bahsedilen üretim 676000 tonlara çıkmıştır. Bunun başlıca nedeni tekne sayısının artmasıdır. Tekne sayısının artışında I. Kalkınma Planında alınan kararlar kısmında bahsedilen ve ardından uygulanan, tekne ve donanımının teminat olarak kabul edilmesi suretiyle, Ziraat Bankası tarafindan kullandırılan kolay kredi olanakları önemli bir rol oynamıştır. Diğer bir sebep ise bu konuda uygulanan gümrük muafiyetidir (DPT 1990). Bunun sonucunda deniz ürünleri üretimi artmış ve kişi başına düşen balık tüketimi, 1963 y1lındaki 2 kg'dan, 1988 y1lında 12.2 kg'a kadar yükselmiştir.

Türkiye'de özellikle 1980 yılından sonra, balıkçı teknelerinin sayı, boy ve motor güçlerinde önemli gelişmeler olmuştur. Tekne sayıs1 1980-2010 döneminde yıllık \%3.05'lik ortalama yıllık artış hızı ile 6764'ten, 16650'ye ulaşmıştır. Aynı dönemde deniz ürünleri üretimi ise, sadece $\% 0.38$ olan y1llık artış hızıyla, 397321 tondan, 445680 tona yükselmiştir. İncelenen dönemde tekne sayısındaki artışa karşın, deniz ürünleri üretimindeki artış, düşük olarak gerçekleşmiştir. Buna bağlı olarak tekne başına üretim, aynı dönemde 58.7 tondan \%54.34 azalarak 26.8 tona gerilemiştir (Çizelge 1). Bu gösterge, deniz ürünleri fiyatından bağımsız olarak balıkçıların gelirlerinin giderek azaldığını göstermektedir. $\mathrm{Bu}$ durum, serbest giriş sisteminin hakim olduğu balıkçılık sektöründe, av gücünün plansız bir şekilde artmasının aşırı avcılığı doğurmasından ve aşırı avcılığın stoklara yaptığı baskıdan kaynaklanmıştır (Atay ve ark. 1995). Nitekim, 1990 yılında aşırı avlanma, kirlilik ve ekolojik değişim nedeniyle denizlerdeki avc1lıktan elde edilen üretim 342017 tona gerilemiş ve bu tarihten sonra belli bir dönem Türkiye'nin su ürünleri ihracat1 azalırken, ithalatı artmıştır (GTHB 2015).

Avlanma için ilk koşul yeterli miktarda balığın olması olsa da, fazla sayıda gemi varlığı ve aşırı avlanma balık stoklarında baskı ve önemli bir azalma yaratmaktadır. Bu nedenle Avrupa Birliği'nin (AB) avlanma filosunu uygun ölçüye getirmek ve o noktada kalmasını sağlamak amacıyla, ortak balıkçılık politikası (OBP) oluşturulmuştur. AB ortak balıkçılık politikasının 1992 yılındaki ilk on yıl değerlendirmesi esas alındığında, Türkiye'de mevcut balık kaynaklarına karşılık, çok fazla gemi bulunduğu belirtilmektedir (Karauçak 2009). Avrupa Birliği ülkeleri toplam filo sayısının ise 2000 yılında 95285 iken, yaklaşık \%13.17 azalarak 2017 y1lında 82737'ye düştüğü gözlenmektedir (EUROSTAT 2018). 2017 yılı itibariyle Türkiye'nin balıkçı filosu, AB'nin \%17.50'si (yaklaşı 1/6's1) oranındadır. $\mathrm{Bu}$ değerlerden anlaşılacağı üzere, halen $\mathrm{AB}$ müzakerelerinde balıkçı filomuzun büyüklüğü sorun oluşturmaktadır.

Diğer taraftan Türkiye'nin sahip olduğu gemilerin \%86's1 10 metreden küçük gemilerdir (TMMOB 2018). Bu kapsamda sürdürülebilir bir balıkçılık için $\mathrm{Su}$ Ürünleri Kanununun yeniden gözden geçirilmesi ve balıkçılıkla ilgili yaptırımların artırılması gerekliliği düşünülmektedir (Sağlam ve Soyer 2017). Sorunun kaynağı olan tekneler daha çok gırgır tekneleri olup, özellikle tehdit altındaki hamsi, sardalya, çaça gibi türleri avlamaktadirlar.

Filo azaltma ve kontrol metotlarından en önemlisi dünya literatüründe de adı geçen geri alım programlarıdır. Bu nedenle, AB-Türkiye müzakerelerinde Ortak Balıkçılık kapsamında 13. Fasıl gereği Türkiye'de de 2012 yılında gemi geri alımları için gemi boyuna göre destekleme uygulaması kararı alınmıştır. Gemi geri alım programı 2013, 2014 ve 2015 yıllarında uygulanmıştır. 2013 yılında 12 metrenin üzerindeki gemiler kapsama alınmışken, 2014 yılında kapsam genişletilerek gemi boyu 10 metreye düşürülmüştür. Program kapsamında, balıkçı gemilerinin boylarına göre 10-20 metre için $10000 \mathrm{TL} \mathrm{m}^{-1}$, 21-30 metre için $15000 \mathrm{TL} \mathrm{m}^{-1}, 31-34$ metre için $20000 \mathrm{TL} \mathrm{m}^{-1}$, $35-45$ metre için $30000 \mathrm{TL} \mathrm{m}^{-1}$ ve 46 metre ve üzeri için 35000 $\mathrm{TL} \mathrm{m}{ }^{-1}$ destekleme ödemesi uygulanmıştır. İsteğe bağlı olarak uygulanan program çerçevesinde, toplamda 1011 balıkçı gemisine yaklaşık 138.6 milyon TL destekleme ödemesi yapılmıştır. Av filosundan çıkarılan balıkçı gemilerinden nitelikleri uygun olanlardan 50 adedi çeşitli kamu kurumlarına devredilirken kalanı Aliağa Söküm Tesislerine ve Makine Kimya Endüstri Kurumuna teslim edilmiştir (Çizelge 2). Üç aşamalı sürdürülmüş olan program ile her bir aşamada yaklaşık \%19'luk bir azalma sağlanabilmiştir (GTHB 2015). Son yıllarda yapılan değişikliklere rağmen, filo sayısında önemli bir düşüş sağlanamadığ̣ gibi, tekne büyüklügüünün 10 metreye indirilmesi de programın başarısını engellemiştir. Diğer taraftan program

Çizelge 1. 1970-2017 yılları arası deniz ürünleri üretimi ve balıkçı teknesi sayısı (TÜiK 2017).

Table 1. Number of seafood production and fishing vessels between 1970-2017 (TÜiK 2017).

\begin{tabular}{cccccccc}
\hline Y1llar & Üretim (ton) & Tekne sayıs (adet) & Tekne başına üretim (ton) & Yıllar & Üretim (ton) & Tekne sayıs1 (adet) & Tekne başına üretim (ton) \\
\hline 1970 & 170905 & 6376 & 26.8 & 2010 & 445680 & 16650 & 26.8 \\
1980 & 397321 & 6764 & 58.7 & 2015 & 397731 & 14340 & 27.7 \\
1990 & 342017 & 8749 & 39.1 & 2016 & 301464 & 14501 & 20.8 \\
2000 & 460521 & 13381 & 34.4 & 2017 & 322173 & 14479 & 22.3 \\
\hline
\end{tabular}

Çizelge 2. Yıllar itibariyle gemi geri alım programından yararlanan tekne sahipleri sayısı ve destekleme tutarı (GTHB 2015).

Table 2. Number of boat owners benefiting from the vessel buyback program and support amount by years (GTHB 2015).

\begin{tabular}{lcccc}
\hline Alım Y1lı & Söküm tesislerine teslim (Adet) & Devredilen (Adet) & Toplam (Adet) & Destekleme tutarı (TL) \\
\hline 2013 & 335 & 29 & 364 & 62083850 \\
2014 & 446 & 10 & 456 & 54028571 \\
2015 & 180 & 11 & 191 & 22515942 \\
Toplam & 961 & 50 & 1011 & 138628363 \\
\hline
\end{tabular}


kapsamında alımı yapılan tüm gemilerin \%94.76's1 (958 tanesi) $10-20 \mathrm{~m}, \% 4.75$ 'i (48 tanesi) $21-30 \mathrm{~m}$ ve sadece $\% 0.49$ 'u (5 tanesi) $31 \mathrm{~m}$ ve üzeri boya sahiptir (GTHB 2015). Burada daha önce $30 \mathrm{~m}$ ve üzeri olarak uygulanan ölçeğin, 2014 yılında büyük teknelerin programa katılımını sağlamak amacıyla, yeniden düzenlendiğini belirtmek gerekmektedir. Böylelikle büyük teknelerin de programa katılımı hızlandırılmak istenmiş, ancak bu konuda bir başarı sağlanamamıştır. Türkiye'de su ürünleri üretiminin \%90'ını karşılayan teknelerin boylarının 18$65 \mathrm{~m}$ arasındaki gırgır ve trollerden oluştuğu ifade edilmektedir (DTO 2015). Oysa programdan yaralanan balıkçılar, daha çok küçük tekne sahipleri olmuşlardır.

Türkiye'deki toplam tekne sayıları incelendiğinde program sonrası balıkçı teknesi sayısının 14500 dolaylarında olduğu ve pek değişmediği, tekne sayısının azalmasına rağmen tekne başına düşen su ürünleri miktarının 2010 yılı değerine göre pek fazla değişmediği görülmektedir (Çizelge 1). Buradan hareketle de programın balık stokları üzerindeki baskıyı pek etkilemediği ve sürdürülebilirliğin sağlanması için pek fazla katkı sağlamadığını söylemek mümkün görülmektedir.

\subsection{Balıkçı ve gemilerin temel özellikleri}

Araştırma kapsamında görüşülen balıkçıların teknelerinin \%64.38'inin Marmara, kalan \%35.62'sinin de Karadeniz Bölgesi limanlarına bağlı oldukları belirlenmiştir. Ankete katılan tüm balıkçıların beklenildiği üzere cinsiyeti, erkektir ve sadece 3 balıkçı bekardır. Balıkçıların \%19'u 35 yaş altı, \%44'ü orta yaş (35-50 yaş) ve \%37'si de 50 ve üzeri yaş grubundadır. Görüşülen en genç balıkçının yaşının 22, en yaşlısının yaşının 70 ve yaş ortalamasının da 45 olduğu belirlenmiştir. Yaş ile doğrudan ilişkili olduğunu söyleyebileceğimiz başka bir özellik te deneyim süresidir. Balıkçıların deneyim süreleri 5 ile 50 yıl arasında değişmektedir. Ortalama deneyim süreleri ise 29 yıldır. $\% 19$ 'u 20 ve alt1, \%44'ü 20-35 aras1 ve \%37'si 35 üstü deneyime sahiptir. $\mathrm{Bu}$ değerler balıçıların balıkçılık deneyimlerinin yüksek olduğunu göstermektedir.

Günümüzde yapılan işteki başarıyı etkileyen en önemli unsurlarından biri eğitimdir. Bu açıdan balıkçılar incelendiğinde araştırmaya katılan balıkçıların yarıya yakını (\%47'si) ilkokul mezunudur. Ortaokul, lise ve üniversite mezunlarının oranı sirasiyla $\% 24, \quad \% 18, \quad \% 11$ şeklindedir. $\mathrm{Bu}$ göstergeler balıkçıların eğitim düzeyinin yetersiz olduğunu göstermektedir. Çalışmada yaş grupları ile eğitim düzeyleri arasındaki ilişki de incelenmiştir. Genç balıkçıların eğitim düzeyinin daha yüksek olduğu ve yaş grubu arttıkça bu durumun tersine döndüğü görülmektedir. $\mathrm{Bu}$ ilişki istatistiksel olarak ta önemli (0.004) olarak bulunmuştur (Çizelge 3). Yeni nesil balıkçıların daha eğitimli olmaları, gelecek açısından olumlu olarak değerlendirilebilir.

Ankete katılan balıkçıların sosyal güvence durumu incelendiğinde, \%92'sinin sosyal güvencesinin bulunduğu ve sosyal güvence türünün $\% 75$ ile BAĞKUR olduğu tespit edilmiştir. İlave olarak \%97'sinin kendi evi bulunmaktadır. Balıkçıların \%5'i balıkçılık dişında ikincil bir meslek sahibidirler.

Kapsama alınan balıkçıların teknelerinin boyu en az $30 \mathrm{~m}$, en fazla $52.2 \mathrm{~m}$ ve ortalama $37.31 \mathrm{~m}$ olarak bulunmuştur. Yine yapılan araştırmada ankete katılan balıkçıların ortalama 20 yaşındaki gemileri ve 10 yıllık makineler ile avlanmakta olduğu tespit edilmiştir. Makine gücü ortalama 1893 HP (Beygir Gücü) olup, en genç tekne 1, en yaşlısı 36 yaşındadır. Ankete katılan balıkçıların ortalama tekne yaşı 20 olduğu için tekneler 20 yaş altı ve 20 dahil 20 yaş üstü olarak 2 gruba ayrıldığında, \%61.6'sının 20 yaş ve üstü çıktığı görülmektedir. Bu kapsamda 30 metre ve üzeri ankete katılan balıçıllk teknesi verileri ile 2017 Avrupa Birliğine bağlı ülkelerin balıkçı filo verileri karşılaştırıldığında filomuzun daha genç olduğu söylenebilir (EUROSTAT 2017).

\subsection{Balıkçıların ekonomik özellikleri ve geri alım programına ilişsin görüleri}

$\mathrm{Bu}$ bölümde öncelikle balıkçıların balıkçılıktan memnuniyet durumları ele alınmıştır. Araştırma sonuçlarına göre, yine balıkçı olurdum diyen ve balıkçılıktan memnuniyet duyan ile başka bir meslek seçerdim diyen balıkçılar eşit orandadır (\%33). Balıç̧ıların \%28'i bu konuda okurdum derken \%6's1 farklı yanıtlar vermişlerdir. $\mathrm{Bu}$ değerler balıkçıların mevcut durumlarından 2/3 oranında memnun olmadıklarını göstermektedir. Yaş gruplarına göre bu veriler incelendiğinde yine balıķı olurdum diyenlerin sayısı genç balıkçılarda 1 (\%7.7), orta yaş grubunda $17(\% 60.7)$ ve ileri yaş grubunda 5 $(\% 20.8)$ kişidir. $\mathrm{Bu}$ değerler genç balıkçıların genel olarak durumlarından memnun olmadıkları şeklinde değerlendirilebilir. Memnuniyet düzeyi orta yaş grubunda oldukça yüksektir. Bu durum istatistiksel olarak ta önemli bulunmuştur $\left(\chi^{2}=15.255\right.$, $\mathrm{P}=0.004)$

Araştırmaya katılan balıkçıların mesleği bırakmaları durumunda yapabilecekleri araştırıldığında; 65 sıklıkla \%89'unun balıkçılık dışında bir geliri olmadığ meslek edindirme kursuna katılmadığı ve paraya dönüştürebilecekleri hobileri bulunmadığı görülmektedir. Yine ankete katılan balıkçıların \%90'ının babasının da balıkçı olduğu ortaya çıkmıştır. Baba mesleğini sürdürmelerine rağmen balıkçıların yarıya yakını (\%49.31'i) çocuğunun balıkçı olmasını istememektedir. Bu konuda yaş grupları arasında farklı bir düşünce söz konusu değildir $\left(\chi^{2}=1.291, \mathrm{P}=0.524\right)$.

Araştırmada denizde çalışılan gün sayısı minimum 120 gün, maksimum 260 gün ve ortalama 221 gün olarak tespit edilmiştir. Bu da ankete katılanların "aktif” balıkçılık yaptığını gösteren önemli bir veridir. Denizde çalışılan gün süresini etkileyen faktörleri bulmak için bir takım incelemeler yapılmıştır. Av araç tipleri ile denizde çalışma günleri arasındaki bağlantıya bakıldığında ANOVA test sonuçlarına göre iki grup ortalamaları arasında anlamlı bir fark olmadığı

Çizelge 3. Balıkçıların yaş grupları ve eğitim düzeyleri karşılaşıırması

Table 3. Comparison of age groups and education levels of fishermen

\begin{tabular}{ccccccc}
\hline \multirow{2}{*}{ Yaş grupları } & \multicolumn{2}{c}{ İlk ve ortaokul mezunları } & \multicolumn{2}{c}{ Lise ve üniversite mezunları } & \multicolumn{2}{c}{ Toplam } \\
\cline { 2 - 7 } & Frekans & Yüzde & Frekans & Yüzde & Frekans & Yüzde \\
\hline 35 yaş altı & 5 & 35.71 & 9 & 64.29 & 14 & 100.00 \\
35-50 yaş arası & 21 & 65.63 & 11 & 34.38 & 32 & 100.00 \\
50 yaşstü & 25 & 96.15 & 1 & 3.85 & 26 & 100.00 \\
Toplam & 51 & 70.83 & 21 & 29.17 & 72 & 100.00 \\
\hline
\end{tabular}

$\chi^{2}=15.550, \mathrm{P}=0.004$. 
anlaşılmaktadır (Çizelge 4). Çalışmada ankete katılan balıkçıların eğitim düzeyleri ile denizde çalıştıkları gün sayısı arasındaki bağlantı incelenmiş ve grupların ortalama değerleri arasında fark bulunamamıştır. Bu durumda kişilerin eğitim düzeyleri denizde kaç gün çalıştıkları ile ilgili değildir, denebilir. Bir diğer inceleme ise balıkçıların yaş grupları ile denizde çalıştıkları gün arasındaki ilişkinin varlığı ile ilgilidir. Yapılan karşılaştırmada yaş grupları ile denizde çalışılan gün arasında da bağlantı bulunamamıştır. İncelemeler sonrasında, denizde çalışma gün sayısının balıkçıların yaşları, eğitim düzeyleri ve teknelerinin av araçları ile anlamlı bir ilgisi olmadığı saptanmıştır.

Ankete katılan balıkçıların avlandıkları bölgeler incelenecek olursa; tekne sahiplerinin \%56'sının ülkenin bütün denizlerini kullandıkları ortaya çıkmıştır. Av araçları içerisinde ise daha çok gırgır gemilerinin tüm denizleri kullandığı saptanmıştır.

Ankete katılan balıkçıların neredeyse tamamının tek geçim kaynağının balıkçılık olduğu bilgisiyle, yıllık toplam satış tutarları incelendiğinde, minimum $1400000 \mathrm{TL}$, maksimum $7500000 \mathrm{TL}$ ve ortalama 3327940 TL satış tutarı olduğu tespit edilmiştir (Çizelge 5). Ankete katılan balıç̧ıların eğitim düzeyleri ile yıllık satış tutarları arasındaki bağlantı için ANOVA testi yapılmış ve grupların ortalama değerleri arasında fark bulunmamıştır. Bu anlamda eğitim kategorisinin de satış tutarını etkilemediği söylenebilir. İlave olarak, yapılan test sonucuna göre, balıkçıların yaş gruplarına göre yıllık ortalama satış tutarlarının da önemli bir farklılık göstermediği belirlenmiştir.

Çalışmada geri alım programından habersiz olan balıkçı ile karşılaşılmamıştır. Programa ilişkin bilgi kaynakları olarak önem sırasına göre Tarım Bakanlığı, Liman İşletmeleri ve arkadaş ve diğer balıkçılar ön plana çıkmaktadır. Ankete katılan balıkçılara söz konusu programa genelde hangi tip tekne sahiplerinin başvurduğu ile ilgili görüşleri sorulduğunda, eski ve hurda diyenlerin oran $\% 65$, ahşap tekne sahipleri diyenlerin oran $\% 16$, fiili balıkçılık yapmayan ve pasif olarak nitelenen balıkçıların oranı $\% 15$ ve küçük tekneler olduğunu söyleyenlerin oran $1 \% 4$ 'tür.

Ankete katılan balıkçılar uygulanan programa katılmasalar da programı, genel olarak faydalı olarak değerlendirmektedirler. Nitekim görüşülenlerin $\% 87.5$ 'i olumlu ve faydalı olduğunu düşündüğünü belirtmiştir. Kalan $\% 12.5$ 'i ise belirlenen bedellerin düşük olduğunu ve bu nedenle talebin az olacağını düşünmektedirler.

Programa katılmama kararındaki olası sebepler araştırıldığında en büyük etkenin ekonomi ile ilgili endişeler olduğu gözlenmektedir. Araştırmada, Geri Alım Programında belirlenen meblağın balıç̧ılara az gelmesi, programa katılmama nedenlerinden en önemli faktör olarak belirlenmiştir. Nitekim görüşülen balıkçıların teknelerine biçtikleri ortalama değer 13723.7 TL'dir. Buna göre teknenin metresine düşen değer $368817 \mathrm{TL} \mathrm{m}^{-1}$ olarak tespit edilmiştir. Kapsama alınan balıkçı gemilerinin ortalama boyu $(37.31 \mathrm{~m})$ dikkate alınarak biçilen değer ile programda uygulanan birim değerler karşılaştırıldığında (35-45 metre için $30000 \mathrm{TL} \mathrm{m}^{-1}$ ), aralarında çok büyük farklılıkların bulunduğu görülmektedir.

Yapılan araştırmada ortalama gemi yaşı ve çalışma günü dikkate alındığında, 20 yıllık teknelerle, 221 gün ile aktif balıkçılık yapan balıkçıların, geri alım programını kendilerine uygun bulmadıkları düşünülebilir. Bunun olası sebeplerinden birisinin ilk üç icra edilen programda, küçük tekne toplayabilen geri alım programının balık üzerindeki baskı1 azaltamayacağına olan inanç gelmektedir. Üretimin \%90'1, boyları 18 ila 65 metre arasında olan trol ve girgır gemileri ile yapılmakta olup, 2015 yılı itibariyle trol ve girgır balıkçılığ 1 yapılan gemi sayısı oran1 \%8.5'dir (TÜİK 2015).

Görüşülen balıkçıların programa katılmama nedenleri ile ilgili frekans dağılımı Çizelge 6'da sunulmuştur. Bu kapsamda incelenen ilk faktör balıkçıların "Balıkçılık dışında para kazanacak başka bir işim yok" düşüncesi olmuştur. Bulgular, balıkçıların durumlarının bu düşünceye uygun koşullarda bulunmalarına karşın, bu durumun programa katılmamaları üzerinde $\% 66$ oranında etkili olmadığını kanıtlamaktadır. Benzer şekilde "Balıkçılık dışında boş zamanlarımı geçirebileceğim bir hobim yok" düşüncesinin de katılmama kararında etkili olmadığı ortaya çıkmıştır. Balıkçılar "Hâlihazırda devletin ödediği teşvikten daha fazlasını kazanıyorum" düşüncesinin kendilerinin katılmama kararında çok etkili olduğunu büyük bir oranda (\%98) ifade etmişlerdir. $\mathrm{Bu}$ durum balıkçıların kazançlarını yeterli gördükleri şeklinde de yorumlanabilir. Benzeri şekilde "Tekneyi vermek yerine ruhsatını kullanarak teknemi yenileyebilirim" ve "Bu teknenin ruhsatını başka birisine devletin ödediğinden daha fazla bir

Çizelge 4. Balıkçıların av araç tipleri itibariyle denizde çalıştıkları gün sayısı istatistikleri

Table 4. Statistics of the number of days that fishermen work at sea by type of fishing gear

\begin{tabular}{|c|c|c|c|c|}
\hline Av arac1 tipleri & Ortalama & Standart sapma & Minimum & Maksimum \\
\hline Girgır & 221.18 & 19.196 & 120 & 240 \\
\hline Trol-girgır & 225.00 & 0.000 & 225 & 225 \\
\hline Diğer - orta su trolü & 215.83 & 42.310 & 120 & 260 \\
\hline Tüm balıkçılar & 220.62 & 23.569 & 120 & 260 \\
\hline
\end{tabular}

$\mathrm{F}=0.360, \mathrm{P}=0.699$.

Çizelge 5. Balıkçıların yaş grupları itibariyle yıllık satı̧s tutarları istatistikleri (1000 TL)

Table 5. Annual sales amount statistics by fishermen age groups (1000 TL)

\begin{tabular}{lcccc}
\hline Yaş grup aralı̆̆ & Ortalama & Standart sapma & Minimum & Maksimum \\
\hline 35 yaş altı & 3291.66 & 940.46 & 1500.00 & 5000.00 \\
$35-50$ yaş arası & 3260.34 & 1123.08 & 1400.00 & 6000.00 \\
50 yaş üstü & 3416.66 & 1381.54 & 2000.00 & 7500.00 \\
Total & 3327.94 & 1190.96 & 1400.00 & 7500.00 \\
\hline
\end{tabular}

$\mathrm{F}=0.124, \mathrm{P}=0.884$. 
Çizelge 6. Görüşülen balıkçıların programa katılmama nedenlerinin frekans dağılımı

Table 6. Frequency distribution of the reasons for the fishermen not participating in the program

\begin{tabular}{|c|c|c|c|c|c|c|}
\hline \multirow{2}{*}{ Faktörler } & \multicolumn{5}{|c|}{ Etki düzeyi* } & \multirow{2}{*}{ Toplam } \\
\hline & 1 & 2 & 3 & 4 & 5 & \\
\hline 1 Balıkçılık dışında para kazanacak başka bir işim yok & 49 & 2 & 2 & 7 & 13 & 73 \\
\hline 2 Balıkçılık dışında boş zamanlarımı geçirebileceğim bir hobim yok & 46 & 3 & 3 & 8 & 13 & 73 \\
\hline 3 Hâlihazırda devletin ödediği teşvikten daha fazlasını kazanıyorum & 1 & 0 & 0 & 1 & 71 & 73 \\
\hline 4 Tekneyi vermek yerine ruhsatını kullanarak teknemi yenileyebilirim & 2 & 0 & 1 & 1 & 69 & 73 \\
\hline $5 \mathrm{Bu}$ teknenin ruhsatını devletin ödediğinden daha fazla bir miktara satabilirim & 0 & 0 & 2 & 2 & 69 & 73 \\
\hline 6 Bu meslek baba mesleğidir, atamam & 5 & 3 & 0 & 2 & 63 & 73 \\
\hline 7 Çocuğumun da bu mesleği yapmasını istiyorum & 31 & 0 & 2 & 0 & 40 & 73 \\
\hline
\end{tabular}

*: 1. Hiç etkisi olmad, 2. Biraz etkisi oldu, 3. Orta düzeyde etkili oldu, 4. Etkili oldu, 5. Çok etkili oldu.

miktara satabilirim" düşüncelerinin de (\%95 oranları ile çok etkili olduğu belirtilerek) en etkili faktörler olduğu tespit edilmiştir. Diğer taraftan balıkçıların önemli bir kısmı baba mesleği olması nedeniyle katılmadıkları yönünde görüş belirtmişlerdir. "Çocuğumun da bu mesleği yapmasını istiyorum" düşüncesi balıkçıların yaklaşık \%50’si geçerli iken, diğer yarısı için geçerli değildir.

\section{Sonuçlar}

Sonuç olarak, gemi geri-alım programının Türkiye'de de uygulanmasının sürdürülebilir balıkçılık yönetimi kapsamında kamunun gerçekleştirdiği yerinde uygulamalardan biri olduğu söylenebilir. Ancak yapılan çalışmada, sürdürülebilir balıkçılık yönetiminde ve stokların korunmasında etkin olan, 30 metre ve üzeri balıkçı teknelerinin bu programa ilgi göstermedikleri ortaya çıkmıştır. $\mathrm{Bu}$ gruptan sadece 5 geminin programa katılması da bu durumu açık olarak göstermektedir. Bazı çalışmalarda programın başarısından söz edilse de (Göktay ve ark. 2018), belirtilen nedenle programın başarısının kısıtlı kaldığını söylemek mümkün görülmektedir. Program öncesi ve sonrası gemi başına yakalanan deniz ürünleri miktarının pek değişmemiş olması da programın sürdürülebilir balıkçılık yönetimine katkısının sınırlı kaldığını göstermektedir.

Eğer hedef balık stokları üzerindeki baskının azaltılması ise, böylesi bir programın başarılı olabilmesi, büyük balıkçı teknesi sahiplerinin programa katılması ile mümkündür. Nitekim yapılan araştırmada; gemi geri alım programında belirlenen gemi bedellerinin balıçılara az gelmesi, programa katılmamanın en önemli faktörlerden birisi olarak belirlenmiştir. Yine söz konusu balıkçıların bu durumdan başka; teşvikten daha fazlasını kazanıyor olma, tekne yenileme ve ruhsat satışı yapabilecek olma ihtimalleri, bu kararı verirken en çok etkilendiği diğer faktörlerin başında gelmektedir. Balıkçılığın baba mesleği olması ise bu kararda \%86 oranında etkili olmuşstur.

Diğer taraftan tartış1lması gereken asıl konu büyük balıkçı teknelerinin sayısının gerçekten azaltılma gerekliliğidir. Bilindiği gibi büyük gemiler, ölçek ekonomisinden yararlanmayı sağlamakta ve rekabetçi ve ekonomik bir şekilde faaliyet gösterebilmektedirler. $\mathrm{Bu}$ açıdan, balıkçı filosunda, ölçeğin büyümesi olumlu bir sonuçtur. Program, filo ölçeğinin büyümesine katkı sağlamıştır. $\mathrm{Bu}$ konuda daha net değerlendirmelerin yapılabilmesi için optimum balıkçı gemisi sayısı ve dağılımının bilinmesi gerekmektedir. Bu tartışmalarda denizlerin uluslararası boyutunun da dikkate alınması gerekmektedir. Filo sayısının yüksekliğinin bu konuda bir avantaj sağlayabileceği de düşünülmektedir.

\section{Kaynaklar}

Aksoy R, Koç G (2012) Küçük ölçekli balıkçılığın genel profili: Zonguldak ili Merkez ilçesinde bir saha çalışması, International Journal of Economic and Administrative Studies 4(8): 87-103.

Atay D, Korkmaz AŞ, Polatsü S, Yıldız H, Rad F (1995) Su ürünleri tüketim projeksiyonları ve üretim hedefleri. Türkiye Ziraat Mühendisliği IV. Teknik Kongresi, II. Cilt, pp. 809-823.

Çeliker A, Korkmaz Ş, Demir A, Gül U, Dönmez D, Demir A, Kalanlar Ş (2006) Karadeniz Bölgesi su ürünleri avcılığının sosyo-ekonomik analizi. Tarım ve Köyişleri Bakanlığı, Tarımsal Ekonomik Araştırmalar Enstitüsü, No: 143, Ankara.

Çeliker A, Korkmaz Ş, Demir A, Gül U, Dönmez D, Özdemir İ, Kalanlar Ş (2008) Ege Bölgesinde su ürünleri avcılığı yapan işletmelerin sosyo ekonomik analizi. Tarım ve Köyişleri Bakanlığı, Tarımsal Ekonomik Araştırmalar Enstitüsü, No: 168, Ankara.

Ceyhan V, Gene H (2014) Productive efficiency of commercial fishing: Evidence from the Samsun Province of Black Sea, Turkey. Turkish Journal of Fisheries and Aquatic Sciences 14: 309-320.

Dartay M, Duman E, Duman M, Ateşşahin T (2009) Keban Baraj Gölü Pertek Bölgesi balıkçılarının sosyo-ekonomik analizi. Ege Üniversitesi Su Ürünleri Dergisi 26(2): 135-138.

Doğan K, Gönülal O (2011) Gökçeada (Ege Denizi) balıkçılığı ve balıkçıların sosyo ekonomik yapısı. Karadeniz Fen Bilimleri Dergisi 2(5): 57-69.

DPT (1990) Altıncı Beş Yıllık Kalkınma Planı, 1990-1994. Yayın NO: DPT: 2174, Ankara.

DTO (2015) Deniz Sektörü Raporu. İstanbul ve Marmara, Ege, Akdeniz, Karadeniz Bölgeleri Deniz Ticaret Odası, İstanbul.

Ekmekçi B, Ünal V (2019) Türkiye'de ikinci kuşak balıkçı gemisi geri alım programının analizi. Ege Üniversitesi Su Ürünleri Dergisi 36 (3): $1-1$.

EUROSTAT (2017) Fisheries Statistics in Detail.http://ec.europa.eu/ Eurostat/statistics-explained/index.php/Fishery_statistics_in_detail. Erişim 15 Ekim 2018.

FAO (2016) The States of World Fisheries and Aquaculture. Food and Agriculture Organization of the United Nations, Roma.

FAO (2018) The States of World Fisheries and Aquaculture. Food and Agriculture Organization of the United Nations, Roma.

Göktay S, Bodur GH, Ünal V (2018) Türkiye'de ilk balıkçı gemisi geri alım programının analizi. Ege Üniversitesi Su Ürünleri Dergisi 35(4): $433-445$.

GTHB (2015) Gıda Tarım ve Hayvancılık Bakanlığı Su ürünleri İstatistikleri http://www.tarim.gov.tr. Erişim 13 Mart 2019.

Güngör H, Zengin M, Güngör G (2007) Socio-economic structure of the deep water pink shrimp fisheries in the Marmara Sea. Tekirdag Ziraat Fakültesi Dergisi 4(3): 261-269.

Güngör G, Zengin M, Yılmaz S, Yılmaz İ (2019) Economic perspective of fishery activities Sea of Marmara in Turkey. Turkish Journal Fishery and Aquatic Science 19(8): 669-680. 
Karauçak S (2009) AB ortak balıkçılık politikasına ilişkin bilgi kaynakları. ETCF, EU-Turkey Chambers Forum. Türk İş Dünyası İçin AB mevzuatı. Morris\&Chapman, Brüksel, Belçika, s. 100-106.

Kurt S, Muse B (1984) Buyback of Fishing Rights in the US and Canada: Implications for Alaska. Presented at the 114 th annual meeting of the American Fisheries Society, Ithica, Newyork, pp. 78 .

Rad S, Delioğlan Ş (2006) Taşucu'nda trol tekne balıkçıları ve sosyoekonomik göstergeler. Türkiye VII. Tarım Ekonomisi Kongresi Bildiriler Kitab1, Antalya, s. 1070-1080.

Sağlam EN, Soyer S (2017) Türkiye'de Su ürünleri Bilgi Sistemi (SUBİS)'ne genel bir bakış. Ordu Üniversitesi Bilim Teknik dergisi 7(1): 57-82.

SUBİS (2018) Su Ürünleri Bilgi Sistemi Resmi İnternet Sitesi. http://subis.tarim.gov.tr. Erişim 12 Eylül 2018.

Taşdan K, Çeliker A, Arısoy H, Ataseven Y, Dönmez D, Gül U, Demir A (2010) Akdeniz Bölgesinde su ürünleri avcılığı yapan işletmelerin sosyo ekonomik analizi. Tarım ve Köyişleri Bakanlı̆̆ı, Tarımsal Ekonomik Araştırmalar Enstitüsü, Yayın No: 179, Ankara.

TMMOB (2018) Ziraat Mühendisleri Odası, Su ürünleri Raporu. www.zmo.org.tr Erişim 12 Eylül 2018.

TÜİK (2015) Türkiye İstatistik Kurumu. Su ürünleri İstatistikleri, Ankara.

TÜİK (2017) Su ürünleri $\quad$ Su istatistikleri https://biruni.tuik.gov.tr/medas/?kn=97\&locale=tr. Erişim 12 Eylül 2018.

Uzmanoğlu S, Soylu M (2006) Karasu (Sakarya) Bölgesi deniz balıkçılarının sosyo-ekonomik yapısı, Ege Üniversitesi Su Ürünleri Dergisi 23(1/3): 515-518.
Ünal V, Hoşsucu H (1996) Foça trollerinin ekonomik analizi. Ege Üniversitesi Su Ürünleri Dergisi 13(1-2): 149-161.

Ünal V (2001) Foça balıkçılığının sosyo-ekonomik analizi ve sürdürülebilirlilik açısından değerlendirilmesi üzerine araștırmalar. Doktora Tezi, Ege Universitesi Fen Bilimleri Enstitüsü, İzmir.

Ünal V (2002) Trol balıkçılığında yatırımın karlılık analizi, Foça (Ege Denizi) Ege Üniversitesi Su Ürünleri Dergisi 19(3-4): 411-418.

Ünal V (2003) Socio-economic analysis of part time small-scale fishery, Foca (Aegean Sea). Ege Üniversitesi Su Ürünleri Dergisi 20: 165172.

Ünal V (2004) Viability of trawl fishing fleet in Foca (the Aegean Sea), Turkey and some advice to central management authority. Turkish Journal of Fisheries and Aquatic Sciences 4: 93-97.

Yamane T (1967) Elementary sampling theory.Prentice-Hall Inc. Englewood Cliffs, New Jersey.

Yaylığlu (2013) Akçokoca (Batı Karadeniz) balıkçılığı ve balıkçıların sosyo-ekonomik analizi. Ormancılık Dergisi 9(1): 35-42.

Yiğit H, Soylu M, Uzmanoğlu S (2009) Sakarya İli göllerinin balıkçı profili. İstanbul Üniversitesi Su Ürünleri Dergisi 24(2): 9-23.

Y1lmaz S, Bilgin E, Olguner M (2017) Evaluation of fishing vessel buyback program implemented in Turkey during EU accession. Journal of Aquaculture Engineering and Fisheries Research 3: 5864.

Yücel Ş (2006) Orta Karadeniz Bölgesi balıkçılığı ve balıkçıların sosyoekonomik durumu. Ege Üniversitesi Su Ürünleri Dergisi 23(1/3): 529-532. 